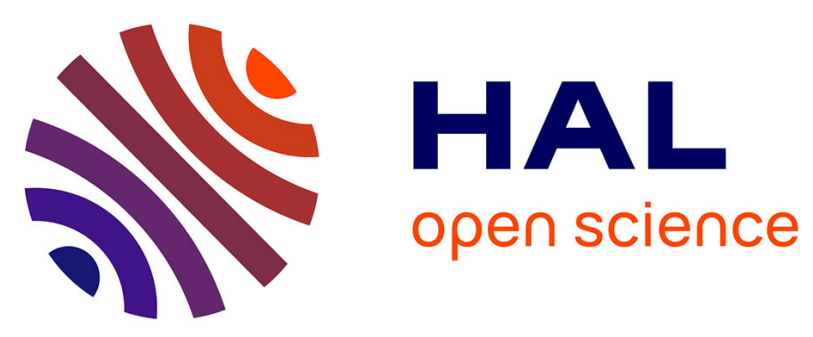

\title{
Combined use of optical and radar satellite data for the detection of tillage and irrigation operations: Case study in Central Morocco
}

\author{
R. Hadria, Benoît Duchemin, Frédéric Baup, Thuy Le Toan, Alexandre \\ Bouvet, Gérard Dedieu, Maël Le Page
}

\section{To cite this version:}

R. Hadria, Benoît Duchemin, Frédéric Baup, Thuy Le Toan, Alexandre Bouvet, et al.. Combined use of optical and radar satellite data for the detection of tillage and irrigation operations: Case study in Central Morocco. Agricultural Water Management, 2009, 96, pp.1120-1127. 10.1016/j.agwat.2009.02.010 . ird-00389251

\section{HAL Id: ird-00389251 https://hal.ird.fr/ird-00389251}

Submitted on 28 May 2009

HAL is a multi-disciplinary open access archive for the deposit and dissemination of scientific research documents, whether they are published or not. The documents may come from teaching and research institutions in France or abroad, or from public or private research centers.
L'archive ouverte pluridisciplinaire HAL, est destinée au dépôt et à la diffusion de documents scientifiques de niveau recherche, publiés ou non, émanant des établissements d'enseignement et de recherche français ou étrangers, des laboratoires publics ou privés. 


\title{
Combined use of optical and radar satellite data for the detection of tillage

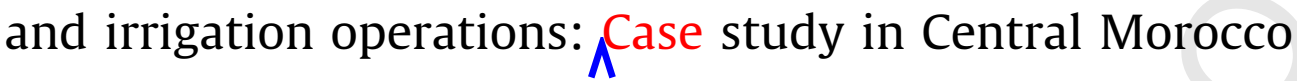

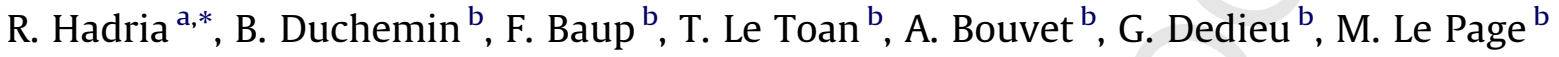 \\ ${ }^{a}$ Faculté des Sciences Semlalia (FSSM), Université Cadi Ayyad, Avenue Prince My Abdellah, BP 2390 Marrakech, Morocco \\ ${ }^{\mathrm{b}}$ Centre d'Etudes Spatiales de la Biosphére (CESBIO), 18 Avenue Edouard Belin, bpi 2801, 3140̂1 Toulouse Cedex 9, France
}

\section{A R T I C L E I N F O}

\section{Article history:}

Received 21 July 2008

Accepted 18 February 2009

\section{Keywords:}

Remote sensing

FORMOSAT

ASAR

Surface state

Changes detection

Agricultural management practices

Tillage

Sowing

Irrigation

\begin{abstract}
A B S T R A C T
The objective of this study is to present a new application of optical and radar remote sensing with high spatial ( $\sim 10 \mathrm{~m}$ ) and temporal (a few days) resolutions for the detection of tillage and irrigation operations. The analysis was performed for irrigated wheat crops in the semi-arid Tensift/Marrakech plain (Central Morocco) using three FORMOSAT-2 images and two ASAR images acquired within one week at the beginning of the 2005/2006 agricultural season.

The approach we developed uses simple mapping algorithms (band thresholding and decision tree) for the characterisation of soil surface states. The first images acquired by FORMOSAT and ASAR were processed to classify fields into three main categories: ploughed (in depth), prepared to be sown (harrowed), and not ploughed-not harrowed. This information was combined with a change detection analysis based on multitemporal images to identify harrowing and irrigation operations which occurred between two satellite observations.

The performance of the algorithm was evaluated using data related to land use and agricultural practices collected on 124 fields. The analysis shows that drastic changes of surface states caused by ploughing or irrigation are detected without ambiguity (consistency index of 96\%). This study provided evidence that optical and radar data contain complementary information for the detection of agricultural operations at the beginning of agricultural season. This information could be useful in regional decision support systems to refine crop calendars and to improve prediction of crop water needs over large areas.
\end{abstract}

(C) 2009 Published by Elsevier B.V.

\section{Introduction}

Half of the world food production originates from irrigated and drained soils (Bastiaanssen et al., 2007), and the monitoring of soil management practices is of prime importance in agri-environmental sciences. Tillage operations affect many biophysical processes such as soil erosion, leaching, run-off and infiltration, nutrient uptake, or carbon sequestration, as well as water and $\mathrm{CO}_{2}$ exchanges (Guérif et al., 2001; Conant et al., in press; Lobb et al., 2007). On short- and mid-term concerns, mechanized soil preparation influences the fragmentation and location of crop Q1 residues (Guerif et al. 2001) as well as the soil infiltration capacity and thermo-hydric properties (Xu and Mermoud, 2003; Chahinian et al., 2006). As a result, tillage has many roles in soil water balance and crop production (Ogban and Babalola, 2002; Aboudrare et al., 2006; Jin et al., 2007). This is particularly true in semi-arid regions as tillage operations affect soil evaporation and water use

\footnotetext{
Corresponding author.

E-mail address: r.hadria@gmail.com (R. Hadria).
}

efficiency (Mrabet, 2000; Aboudrare et al., 2006; Casa and Lo Cascio, 2008).

Sustainable management of agricultural and water resources requires to perform accurate simulations with crop-water balance coupled models at a regional scale. However, shortage of geolocated data on agricultural practices limits the operational use of crop models over large areas (Boote et al., 1996; Moulin et al., 1998; Faivre et al., 2004; Bastiaanssen et al., 2007). An alternative approach may consist in using remote sensing data to detect changes in soil surface states and relate them to agricultural operations.

In the optical domain, it is known from the early seventies that top-soil water causes a general decrease of surface reflectance (Skidmore et al., 1975; Muller and Décamps, 2000; Lobell and Asner, 2002). As well, the increase of surface roughness causes shadowing and a subsequent reduction of reflectances depending on illumination and viewing measurement conditions (Cierniewski, 1989; Jacquemoud et al., 1992). In addition, many properties affect soil spectra, e.g. mineral composition, amount of organic matter, particle size distribution, presence of crusts (Jacquemoud et al., 1992; Mathieu et al., 1998; Nagler et al., 2000;

0378-3774/\$ - see front matter (c) 2009 Published by Elsevier B.V. doi:10.1016/j.agwat.2009.02.010 
Chappell et al., 2006). However, these last properties experience a much lower spatio-temporal variability than surface roughness and topsoil moisture.

Synthetic Aperture Radar (SAR) imagery is known to be governed by two key parameters: surface roughness and soil dielectric constant, the latter being linked to soil moisture (e.g. Ulaby et al., 1986; Beaudoin et al., 1990; Fung et al., 1992; Benallegue et al., 1995; Davidson et al., 2000; Zribi et al., 2005). The general trends of the radar response as a function of both these surface parameters and the sensor characteristics (frequency, incidence, polarisation) are well captured by backscatter models, but the operational applicability of inversion schemes is still challenging. The explanation is twofold: (1) land surfaces are complex and it is difficult to estimate appropriate roughness parameters (Davidson et al., 2000), (2) the relative impact of surface roughness, top-soil moisture and vegetation canopies is hard to decouple (Wagner et al., 1999; Satalino et al., 2003).

Given the sensitivity of optical and radar data to surface roughness and topsoil moisture, the recent design of satellite sensors providing both high spatial resolution $(\sim 10 \mathrm{~m})$ and frequent revisit time (a few days) may offer interesting perspectives. This is the case of: (1) the FORMOSAT-2 satellite (http:// www.nspo.org.tw), launched in May 2004, which can observe a particular area every day at $8 \mathrm{~m}$ spatial resolution in the multispectral mode; (2) the Advanced Synthetic Aperture Radar (ASAR) onboard the ENVISAT mission (http://envisat.esa.int/), which provide images at a spatial resolution of about $30 \mathrm{~m}$ in the Alternating Polarisation mode. The orbital cycle of ENVISAT/ASAR is 35 days, but the revisit time is a few days when acquisitions with different sun-target-sensor geometry are combined.

In Duchemin et al. (2008a), we have illustrated how some agricultural operations (disking, harrowing, irrigation) cause rapid changes in surface reflectances derived from time series of FORMOSAT images. In this study, the objective is to apply mapping algorithms on both FORMOSAT and ENVISAT/ASAR data for the detection of these agricultural operations over a short period of time. The analysis was performed for an irrigated area located in the semi-arid Tensift/Marrakech plain - Central Morocco - where wheat crops are dominant. We used three FORMOSAT images and two ASAR images acquired within one week at the beginning of the 2005-2006 wheat cropping season. After the presentation of this material (Section 2), we successively discussed (Sections 3-5) the methods and results in relation to three questions: (1) How to identify tillage practices using the first satellite observations? (2) How to monitor harrowing and irrigation operations between two successive observations? and (3) How to map soil management practices by combining the previous results? Conclusions and perspectives were then drawn in Section 6.

\section{Material}

\subsection{Remote sensing data and processing}

The FORMOSAT-2 Taiwanese satellite was launched in May 2004. The Remote Sensing Instrument (RSI) onboard FORMOSAT-2 provides high spatial resolution images $(8 \mathrm{~m}$ in the multispectral mode at nadir viewing) in four narrow spectral bands ranging from $0.45 \mu \mathrm{m}$ to $0.90 \mu \mathrm{m}$ (blue, green, red and near-infrared). Unlike other systems operating at high spatial resolution, FORMOSAT-2 may observe a particular area every day with the same viewing angle. However, only a part - about the half - of the Earth may be observed. More details about the specific orbital cycle and other characteristics of the FORMOSAT-2 mission could be found in Chern et al. (2006, 2008) as well as on internet (http:// www.nspo.org.tw, http://www.spot-image.com).
We used three FORMOSAT images as part of a time series collected in the semi-arid Tensift/Marrakech plain in Morocco (Duchemin et al., 2008a). They were acquired at the beginning of the wheat cropping season - December 8, 12 and 16, 2005, around 10:30 GMT - with a nearly constant sun-target-sensor configuration (viewing angle of $18.5^{\circ}$, solar elevation of about $35^{\circ}$ ). The images were georeferenced using an autocorrelation algorithm and a set of ground control points collected with GPS. Accuracy in geolocalisation was estimated to about half-pixel $(4 \mathrm{~m})$. The atmospheric correction was performed using the SMAC code (Rahman and Dedieu, 1994) with atmospheric water vapour content and aerosol optical depth collected by CIMEL sunphotometers installed in the vicinity of the study area. The quality of atmospheric correction is discussed in Hagolle et al. (2008).

The Advanced Synthetic Aperture Radar (ASAR), onboard the ENVISAT mission (http://envisat.esa.int/) launched in March 2002, operates at C-band (frequency $5.33 \mathrm{GHz}$, wavelength $5.6 \mathrm{~cm}$ ) with 7 different incidence angles between $15^{\circ}$ and $45^{\circ}$. The orbital cycle of ENVISAT/ASAR is 35 days, but the combination of different illumination/viewing configurations allows to increase the repetitivity of observations (e.g. 10 passes during the 35-day orbital cycle at $45^{\circ}$ latitude). Between December 2005 and June 2006, 16 ASAR Alternating Polarisation images were collected, all in ascending pass and at high incidence angles (IS5 to IS7). The images were acquired in vertical and horizontal polarisations (VV and $\mathrm{HH}$ ) at a spatial resolution of about $30 \mathrm{~m}$. Radiometric calibration was performed following the procedure specified by the European Space Agency (Rosich and Meadows, 2004). All the images were superimposed using an automatic correlation algorithm based on contrasted objects visible in the images. After superimposition, a spatio-temporal filter was applied to reduce speckle effects. The filter is described in Lopes et al. (1993), Le Toan et al. (1997), and Quegan and Yu (2001).

After this pre-processing, we selected the two ASAR images collected at the beginning of the wheat cropping season, December 10 and 13,2005 , acquired with $35.8^{\circ}$ and $45.2^{\circ}$ incidence angle, respectively. These two ASAR images were coregistered on FORMOSAT data using image-to-image correction (ENVI software, ( ITT Visual Information Solutions). Accuracy in coregistration was estimated to about 1 pixel (12.5 m).

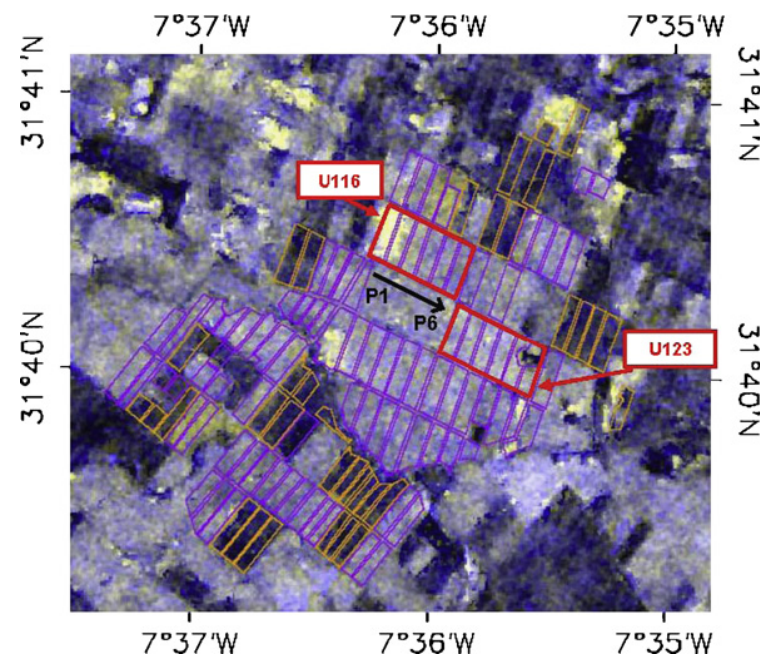

Fig. 1. Location of the fields of study on an ASAR composite image (image of $13 / 12$ in Q5 red and green, image of 10/12 in blue). Wheat and non-cultivated fields are delineated by magenta and orange lines, respectively. Magenta lines show two particular irrigation units, with the field numbering direction indicated by the arrow. (For interpretation of the references to color in this figure legend, the reader is referred to the web version of the article.) 
Table 1

Timing of successive agricultural operations for wheat fields under conventional and reduced tillage. Starting and/or ending day is indicated when known.

\begin{tabular}{|c|c|c|c|c|c|c|c|c|}
\hline \multicolumn{4}{|c|}{$\begin{array}{r}\text { Time: } \\
\quad \text { Year } \\
\end{array}$} & 2005 & & & & \multirow{2}{*}{$\begin{array}{l}2006 \\
\text { January }\end{array}$} \\
\hline \multicolumn{2}{|c|}{$\begin{array}{c}\text { Tillage } \\
\text { Practice }\end{array}$} & $\begin{array}{r}\text { Agricultural } \\
\text { operation }\end{array}$ & Month & July --> & October & November & December & \\
\hline \multirow{4}{*}{ 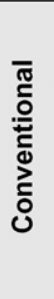 } & & $\begin{array}{r}\text { Ploughing } \\
\text { (depth } \sim 30 \mathrm{~cm} \text { ) }\end{array}$ & & & & & & \\
\hline & \multirow{3}{*}{ 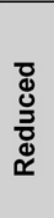 } & $\begin{array}{r}\text { Harrowing } \\
\text { (depth } \sim 10-15 \mathrm{~cm})\end{array}$ & & & & & & \\
\hline & & Sowing & & & & $28 \ldots$ & & $\ldots 5$ \\
\hline & & Irrigation & & & & & $12 \ldots$ & \\
\hline
\end{tabular}

\subsection{Experimental set up}

The experiment was set up during the 2005-2006 wheat agricultural season on an irrigated area located at $40 \mathrm{~km}$ East of Marrakech. This area was intensively monitored as part of the SUDMED program (Chehbouni et al., in press; Duchemin et al., 2006, 2008a,b; Hadria et al., 2006, 2007; Er-Raki et al., 2007). It covers about 2800 ha and is almost flat (slope less than 1\%), with deep soil of xerosol type and a fine, clay to loamy, texture.

Land-use information and soil management practices were collected on 124 fields within the study area. The fields were delineated by digitizing the FORMOSAT images, and, after the filtering procedure, they can be easily identified on ASAR images (Fig. 1). Amongst these fields, about the quarter (35) was not cultivated. The remaining fields were cultivated with wheat under conventional or reduced tillage practices on 64 and 25 fields, respectively.

Table 1 presents the timing of the successive soil management operations associated to conventional tillage (CT) and reduced tillage (RT). In the first case, the soil is ploughed to a depth of 30$40 \mathrm{~cm}$ immediately or few weeks after harvest (July to October). In both cases (CT and RT), the soil is harrowed to a depth of $10-15 \mathrm{~cm}$ a few days or just before the sowing (November to December) in order to level the surface and to prepare seedbed. In what follows these two operations are referred to as ploughing and harrowing, respectively. Finally, wheat seeds are placed using a conventional planter with a seeding rate ranging from 100 to $150 \mathrm{~kg} /$ ha (Hadria et al., 2007). Sowing dates ranged between November 28, 2005 and January 05,2006 . The fields were not flattened with a roller after sowing and there was no significant difference in soil surface states between harrowed and sown fields.

The study area is subdivided in many irrigation units that consist of an average of six fields of 4 ha (e.g. units 116 and 123 in Fig. 1). Irrigation is of flooding type, with the water provided by the regional public agency in charge of dam water management (ORMVAH). Irrigation water is supplied to the fields through an aerial network of concrete channels. About 3 weeks are required to irrigate the whole area. In 2005, the first irrigation round started on December 12 (see Table 1 ).

Climate is basically of semi-arid continental type. Climatic data were provided by a meteorological station installed at the center of the study area (near irrigation unit 116, see Fig. 1), and five rain gauges of the ORMVAH network located in the vicinity of the study area. According to these data, the beginning of the 2005-2006 agricultural season was very dry. Two minor rainfall events (10$15 \mathrm{~mm}$ ) occurred mid- and end-November, after which no rain wâs recorded until December 21. As a consequence, the soil moisture was low, except in case of irrigation. Soil water content was measured using a gravimetric method on eight fields (3-5 samples by field) between November 26 and December 20. Soil moisture ranged from 0.04 to $0.09 \mathrm{~m}^{3} / \mathrm{m}^{3}$ in the top layer $(0-3 \mathrm{~cm})$, and from 0.07 to $0.19 \mathrm{~m}^{3} / \mathrm{m}^{3}$ in the $3-15 \mathrm{~cm}$ layer. Given the clay-loamy texture of soils, these values indicate very dry surfaces. Another consequence of this drought is that plant emergence was delayed. This year, emergence mainly occurred after the first effective rainfall at the end of December (see Duchemin et al., 2008b).

\section{Characterisation of initial soil state-identification of tillage practices}

The optical and radar responses were first analysed from the two first images, i.e. the FORMOSAT image acquired on December 8 and the ASAR image acquired on December 10, both before the first irrigation round. The average values of surface reflectances $(\rho)$ and backscattering coefficient $\left(\sigma^{0}\right)$ were computed over all the fields of study. The detection of surface states was thus investigated at the field scale, without accounting for the intra-field variability. We restricted the analysis to the fields with a minimum size of 1.6 ha; this corresponds to about 100 ASAR pixels, resulting in an accuracy on $\sigma^{0}$ of $0.3 \mathrm{~dB}$ at $90 \%$ of confidence interval.

Fields were distinguished using four categories: (1) noncultivated; (2) already ${ }^{1}$ sown, thus harrowed; (3) not yet ${ }^{1}$ harrowed - Conventional Tillage (ploughed); (4) not yet ${ }^{1}$ harrowed - Reduced Tillage (not ploughed). The two first categories were directly extracted from the field database, while we retained the fields that were sown the latest (from December 27, 2005 to January 5, 2006) to define the two last categories. These categories are associated to different surface roughness (see Davidson et al., 2000 for a statistical study), and three distinctive groups of fields were discriminated in order to analyse the radar and optical responses:

1) Group P - Ploughed fields - corresponding to the 3rd category.

2) Group H - Harrowed fields - corresponding to the 2nd category.

3) Group NP/NH - Nor Ploughed/Neither Harrowed fields - which encompasses the 1 st and 4 th categories.

Fig. 2 shows the comparison between field-averaged reflectances ( $\rho_{\mathrm{NIR}}$, FORMOSAT observations) and backscattering coefficients $\left(\sigma_{\mathrm{VV}}^{0}\right.$, ASAR observations). The dynamic ranges of satellite observations were the largest for the near infrared (NIR) waveband and the vertical (VV) polarisation, but additional plots obtained with other FORMOSAT spectral bands and with backscattering coefficient in horizontal polarisation look quite similar (not shown here).

\footnotetext{
${ }^{1}$ The terms 'not yet' and 'already' are relative to the time of acquisition of the images.
}

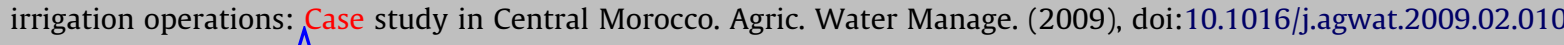




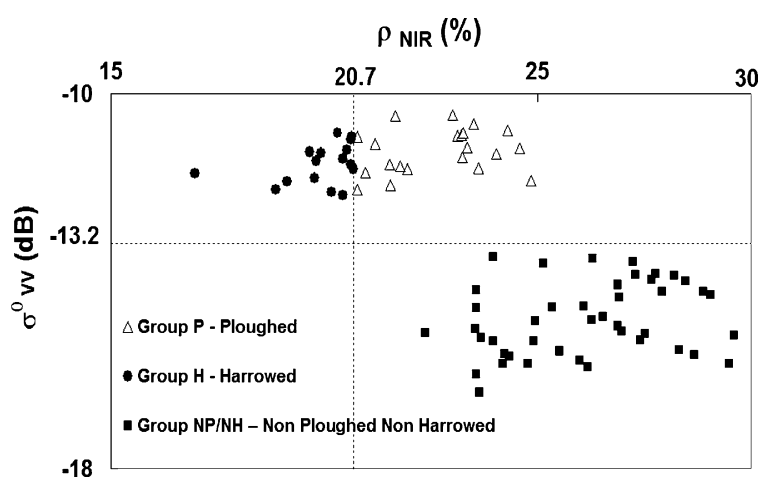

Fig. 2. Scatterplot of ASAR backscattering coefficient in $\mathrm{VV}$ polarisation $\left(\sigma_{\mathrm{VV}}^{0}\right.$, December 10) versus FORMOSAT near infrared reflectances $\left(\rho_{\mathrm{NIR}}\right.$, December 8$)$ for the three categories of surface states. The values correspond to field averages. Dotted lines indicate the cluster boundaries used to classify soil surface states.

In Fig. 2, it can be seen that the NIR reflectances vary from about 15 to $30 \%$, with a clear differences between smooth surfaces (group $\mathrm{NP} / \mathrm{NH}, \rho_{\mathrm{NIR}}>22.5 \%$ ) and sown fields (group $\mathrm{H}, \rho_{\mathrm{NIR}}<20.7 \%$ ), while intermediate values are observed for the ploughed fields (group P, $\rho_{\text {NIR }}$ between $20.8 \%$ and $25 \%$ ). There is not the same hierarchy between these levels of reflectances and the ranges of roughness established by Davidson et al. (2000). It can be understood that recently harrowed fields display more shadows (sharp clods without crusts) and higher topsoil moisture than old ploughed fields that were smoothed by wind erosion, crusting and drying. As a consequence, there are overlaps in the reflectances between ploughed and non-cultivated fields.

In contrast, the ASAR backscattering coefficient appears very sensitive to surface roughness, whatever its origin, i.e. recent harrowing or older ploughing (Fig. 2). $\sigma_{\mathrm{VV}}^{0}$ ranges between $-16.4 \mathrm{~dB}$ and $-13.5 \mathrm{~dB}$ for the group $\mathrm{NP} / \mathrm{NH}$ (smooth surfaces), whereas it is always higher than $-12.2 \mathrm{~dB}$ for both group $\mathrm{P}$ and $\mathrm{H}$ (rough surfaces). ${ }^{2}$ It can be observed that the gap in $\sigma_{\mathrm{VV}}^{0}$ values between the two groups is much larger than the uncertainty on $\sigma_{\mathrm{vV}}^{0}$ $(0.3 \mathrm{~dB})$. However, it appears impossible to separate ploughed fields from harrowed fields. The explanation lies in the saturation of the radar response to surface roughness (see Ulaby et al., 1986; Altesse et al., 1996; Zribi et al., 2005).

Finally, one can notice the complementarity of FORMOSAT and ASAR observations: reflectances allow to clearly identify fields of group $\mathrm{H}$ (red circles in Fig. 2), while backscattering coefficients allows to separate those of group NP/NH (brown squares in Fig. 2). By crossing optical and radar observations, it is thus possible to discriminate the three groups ( $\mathrm{NP} / \mathrm{NH}, \mathrm{H}$ and $\mathrm{P}$ ) without ambiguity. We used simple band thresholding $\left(20.7 \%\right.$ on $\rho_{\mathrm{NIR}}$ and $-13.2 \mathrm{~dB}$ on $\left.\sigma_{\mathrm{VV}}^{0}\right)$ as a clustering procedure to obtain the three following classes:

(1) harrowed fields, with high backscattering coefficients and low reflectances;

(2) ploughed fields, with both high reflectances and backscattering coefficients;

(3) not ploughed-not harrowed fields, with high reflectances and low backscattering coefficients, non-cultivated areas being included in this last category.

This clustering was applied to obtain a complete map of initial soil surface states over the fields of study. The fields that were not used to analyse satellite data in Fig. 2 were all classified as

\footnotetext{
${ }^{2}$ These two ranges of backscattering coefficients clearly appear in ASAR images (compare in Fig. 1 the brightness between wheat fields and non-cultivated areas).
}

harrowed or ploughed on December 10. This appears in agreement with their sowing dates recorded from field survey, which ranged from December 13 to 26.

\section{Change detection-identification of ploughing and irrigation practices}

Time series of field-averaged near infrared reflectances $\left(\rho_{\mathrm{NIR}}\right.$ from FORMOSAT, December 8, 12 and 16, constant sun-targetsensor geometry) and backscattering coefficients ( $\sigma_{\mathrm{VV}}^{0}$ from ASAR, December 10 and 13, with two different incidence angles) were analysed on several particular fields for which the timing and the nature of agricultural operations were accurately collected. Fig. 3a-f shows three typical cases of $\rho_{\mathrm{NIR}}$ and $\sigma_{\mathrm{VV}}^{0}$ time courses on fields where no change, harrowing or irrigation occurred.

\subsection{Stable surfaces}

Fig. 3a and b display four fields where no changes were observed between the first and the last satellite observations. $\rho_{\mathrm{NIR}}$ remains quite stable around a value that depends on the initial surface state, with a slight positive slope of about 3\% in relative value (Fig. 3a). The slight increase of reflectances can be due to residual error in atmospheric correction, the small decrease of sun elevations between December 8 and 16, or a trend of the surface to become smoother (erosion) and/or dryer (last rainfall observed on November 30).

In contrast of reflectances, there is a general decrease of backscattering coefficients from December 10 to 13 (Fig. 3b), ${ }^{3}$ due to the increase of ASAR incidence angle from IS5 to IS7 configuration. The level of $\sigma_{\mathrm{VV}}^{0}$ appears governed by surface roughness, though quite the same for old ploughed and recently harrowed fields. The decrease of $\sigma_{\mathrm{VV}}^{0}$ with incidence angle appears similar for both smooth and rough surfaces (around $-1.7 \mathrm{~dB}$ ). This appears promising in the perspective to normalise ASAR images acquired in different geometric configurations.

\subsection{Harrowing}

Fig. $3 c$ and d present five fields that were harrowed between December 8 and 16 . Looking at $\rho_{\mathrm{NIR}}$ and $\sigma_{\mathrm{VV}}^{0}$ time courses on the three adjacent fields within irrigation unit 123 (full lines in Fig. 3c and $d$ ) is very instructive. Indeed, a visual examination of the second FORMOSAT image acquired on December 12 allows to verify that the farmer was harrowing the 22 field $^{4}$ at the exact time of the satellite overpass; more precisely, the p3 field ${ }^{4}$ was already totally harrowed, about two-thirds of the p2 field was harrowed, while the 1 field was not yet harrowed. This is consistent with the time courses of near infrared reflectances (Fig. 3c): $\rho_{\text {NIR }}$ displays a continuous decrease of reflectances between December 8 and 16 on the $\mathrm{p} 2$ field while the decrease is more obvious and limited in time, either between December 8 and 12 (p3 field, harrowed before the second FORMOSAT overpass) or between December 12 to 16 (p1 field, harrowed after the second FORMOSAT overpass). In contrast, the temporal variation of $\sigma_{\mathrm{VV}}^{0}$ (Fig. 3d) appears the same as those of stable areas, even for p2 field that was harrowed on December 12 between the two ASAR acquisitions. This is due to the fact that these fields were ploughed in depth before being harrowed (conventional tillage).

Looking at $\rho_{\mathrm{NIR}}$ and $\sigma_{\mathrm{VV}}^{0}$ time courses on the two remaining fields (irrigation unit 20, dotted lines in Fig. 3c and d) confirmed that both ASAR and FORMOSAT offer the possibility to detect

\footnotetext{
${ }^{3}$ This decrease also explains the general blue colour in the time composite image presented in Fig. 1.

4 These fields are located in Fig. 1.
} 

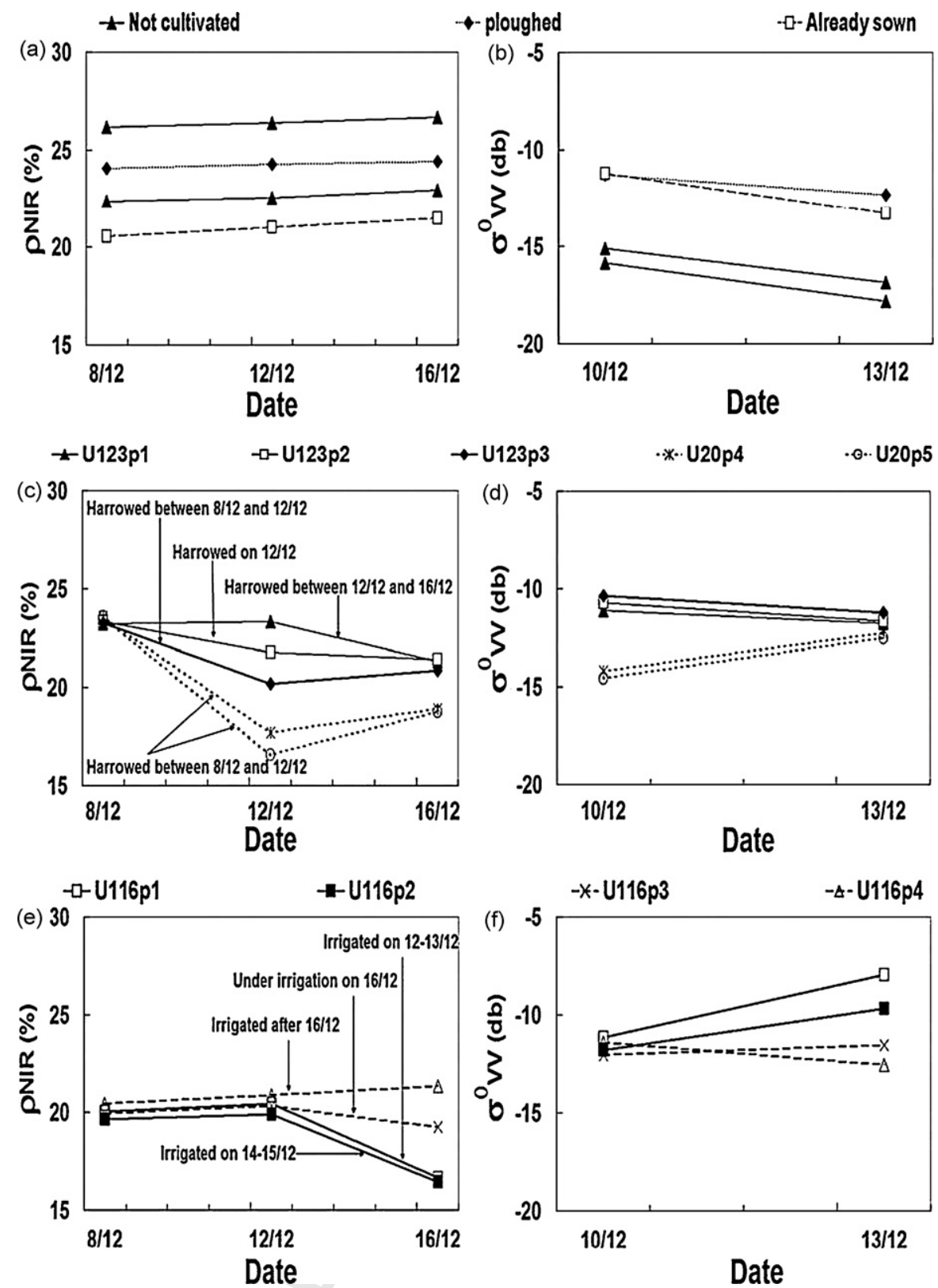

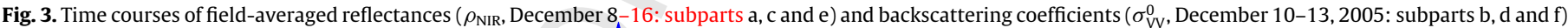

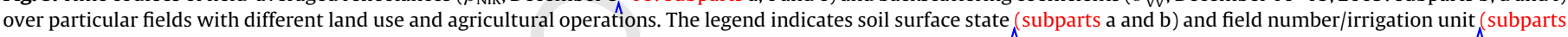
c-f).

harrowing on the fields cultivated with reduced tillage practices. These fields were not ploughed before being harrowed, and there is a sharp increase of $\sigma_{\mathrm{Vv}}^{0}$ between December 10 and 13, which contrasts with the general decreasing trend. This atypical behaviour is caused by the increase of surface roughness after harrowing. For these two fields, it is thus possible to use both radar and optical images to date the harrowing between December 10 (ASAR first acquisition) and 12 (FORMOSAT second acquisition).

\subsection{Irrigation}

In Fig. $3 e$ and $\mathrm{f}$, the time courses of near infrared reflectances and backscattering coefficients are plotted for four fields where irrigation occurred before December 16 . These fields, which belong to irrigation unit 116 , were all sown around December 1 . The field database also indicates that the whole irrigation of unit 116 (6 fields, see Fig. 1) was achieved in nine days, between December 12 and 20 , starting by $\mathrm{p} 1$ field. These irrigations can be clearly detected by a drop of $\rho_{\mathrm{NIR}}$ between December 12 and 16 and a rise of $\sigma_{\mathrm{Vv}}^{0}$ between December 10 and 13. This is not surprising since irrigation results in both an increase of topsoil moisture and a decrease of surface roughness (water erosion)

However, the schedule deduced from the two types of images appears somewhat inconsistent. Looking at FORMOSAT images and $\rho_{\text {NIR }}$ time courses (Fig. 3e) allowed to state that: (a) p1 and p2 fields were irrigated between December 12 and 16; (b) p3 field was under irrigation at the exact time of satellite overpass, on December 16; (c) the p4 field was not yet irrigated on December 16. This is consistent with the information recorded by field survey: two fields and half were irrigated in less than four days; this duration is coherent with the period of nine days needed to irrigate the six fields of the irrigation unit. On the other hand, $\sigma_{\mathrm{vv}}^{0}$ increases on the $\mathrm{p} 1$ field, the $\mathrm{p} 2$ field and, though on a less extent, on the p3 field (Fig. 3f). This seems to indicate that these three 
fields were irrigated before December 13, in contradiction with the previous statements on irrigation duration. This anomaly is the result of the filtering applied on radar data, which is based on the assumption of surface stability on a spatial neighbouring (11 pixels, about $140 \mathrm{~m}$ ). It appears that fields with low $\sigma_{\mathrm{VV}}^{0}$ in the surroundings of fields with large $\sigma_{\mathrm{VV}}^{0}$ appeared contaminated, and their backscattering coefficients were overestimated. This contamination is noticeable around irrigation unit 116 in field p1 as well as in some other parts of the study area (e.g. nearby the two northern studied fields or at the eastern part of the study area, see Fig. 1). In patchy agricultural landscapes, it may be more appropriate to incorporate the actual delimitation of fields during the processing scheme of radar data.

\section{Mapping of soil management practices: algorithms and results}

The final algorithm is a decision tree that integrates the a priori knowledge on schedules of agricultural operations (Section 2.2), the map of initial soil surface states (Section 3), and two additional rules derived from the change detection analysis (Section 4 ). These rules are applied on the successive satellite observations: a decrease of near infrared reflectances, by more than $1 \%$ in relative value, as well as an increase of backscattering coefficients, indicates either harrowing or irrigation. Initial surface states provide the three main branches at the basis of the decision tree, which operates as follows:

(1) On "not ploughed-not harrowed" fields: a change indicates that harrowing occurred, and the combination of ASAR and FORMOSAT images allows an optimal dating of the operation. (2) On "ploughed-not harrowed" fields: a change is also a harrow, but it can only be detected on FORMOSAT images.

(3) On harrowed fields, a change indicates that irrigation occurred, and both ASAR and FORMOSAT can be used to detect this operation, provided the pre-processing of radar data was improved.

The decision tree was applied to time series of field-averaged $\rho_{\mathrm{NIR}}$ and $\sigma_{\mathrm{VV}}^{0}$ acquired between December 8 and 16 . It provided a map containing the initial surface states and, if a change is detected, both the type of agricultural operation and the period of its occurrence (Fig. 4). This map was evaluated against the field data collected on the study area (Tables 2 and 3). This analysis confirmed the performance of the algorithm:

- All the changes identified from ASAR images, between December 10 and 13, were also identified with FORMOSAT, either between December 8 and 12 or between December 12 and 16 .

- No change was detected on non-cultivated fields (compare red empty polygons in Fig. 4 and orange polygons in Fig. 1).

- There was only one field for which a harrowing is detected after the sowing date declared in the database (Table 2, consistency index of 97\%). Amongst wheat fields included in the "not ploughed-not harrowed' category, the sowing dates of the four fields where a harrowing was identified between December 10 and 12 (red dashed polygones in Fig. 4) ranged between December 10 and 14, the - single - field where a change was identified between December 13 and 16 (red dotted polygone in Fig. 4) was declared sown on December 14 , and no change was detected on the remaining three fields that were declared sown after December 16 .

- Irrigation was dêtected on the 6 fields that were sown the earliest (between November 28 and December 6). These 6 fields were recorded as irrigated between December 12 and 16, except one for which the irrigation date was December 18 in the database

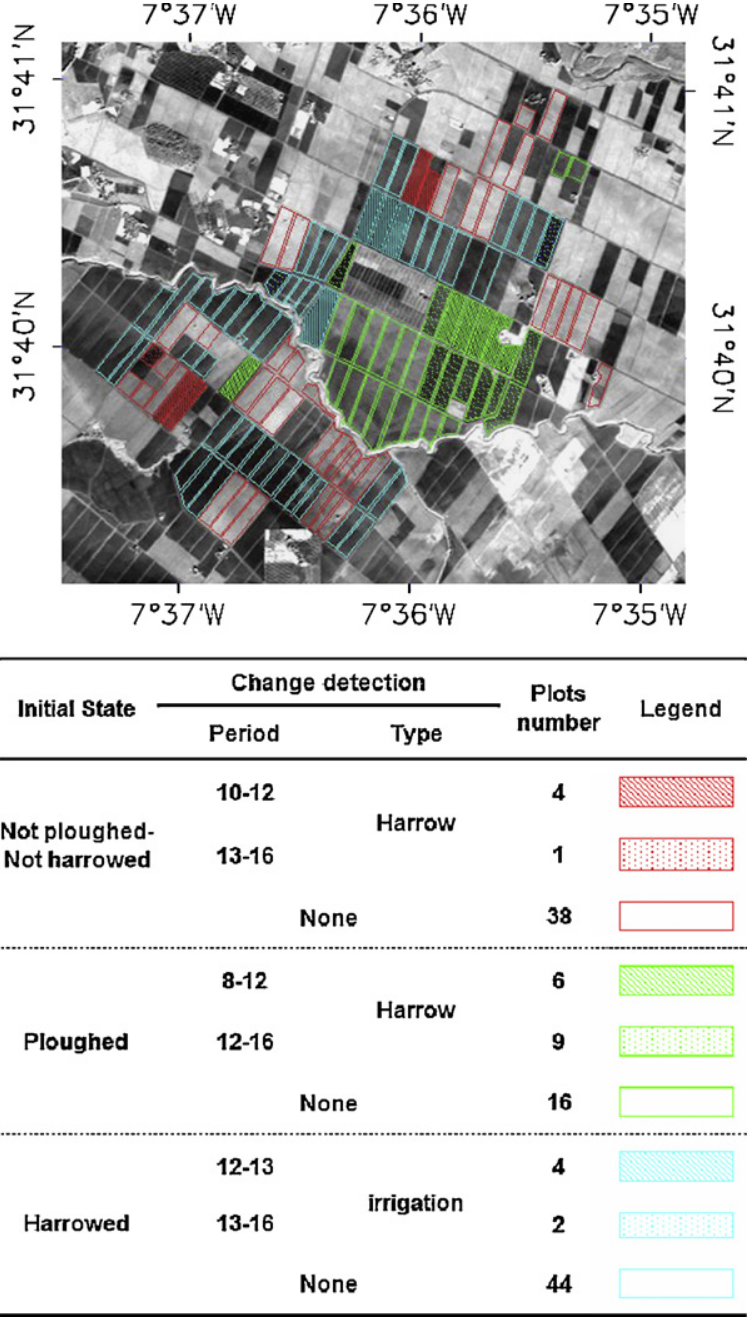

Fig. 4. Map of agricultural practices over the study area. The legend indicates the initial soil surface state (first column) as well as the period and type of agricultural operations that occurred between December 8 and 16, 2005 (second main column).

Table 2

Evaluation of harrowing detection results from field observation data. Consistency index corresponds to the number of fields for which the detection is consistent with the observation (in percentage).

\begin{tabular}{llll}
\hline $\begin{array}{l}\text { Detected harrowing } \\
\text { period }\end{array}$ & $\begin{array}{l}\text { Fields } \\
\text { number }\end{array}$ & $\begin{array}{l}\text { Observed } \\
\text { sowing period }\end{array}$ & $\begin{array}{l}\text { Consistency } \\
\text { index }\end{array}$ \\
\hline Before $08 / 12$ & 16 & $24 / 12-5 / 01$ & $100 \%$ \\
$08 / 12-12 / 12$ & 6 & $26 / 12^{\wedge}-31 / 12$ & $100 \%$ \\
$10 / 12-12 / 12$ & 4 & $10 / 12^{\wedge}-14 / 12$ & $100 \%$ \\
$12 / 12-16 / 12$ & 9 & $13 / 12^{\wedge}-31 / 12$ & $100 \%$ \\
$13 / 12-16 / 12$ & 1 & $14 / 12^{\wedge}$ & $100 \%$ \\
After $16 / 12$ & 3 & $14 / 12-27 / 12$ & $66 \%$ \\
\hline
\end{tabular}

(Table 3, consistency index of 83\%). Conversely, the fields where no irrigation was detected were all declared irrigated after December 20. These findings appear satisfactory with regard to the accuracy of the field survey.

Table 3

Evaluation of irrigation detection results from field observation data. Consistency index corresponds to the same as in Table 2.

\begin{tabular}{llll}
\hline $\begin{array}{l}\text { Detected irrigation } \\
\text { period }\end{array}$ & $\begin{array}{l}\text { Fields } \\
\text { number }\end{array}$ & $\begin{array}{l}\text { Observed } \\
\text { sowing period }\end{array}$ & $\begin{array}{l}\text { Consistency } \\
\text { index }\end{array}$ \\
\hline $13 / 12-16 / 12$ & 2 & $4 / 12-6 / 12$ & $100 \%$ \\
$12 / 12-13 / 12$ & 4 & $1 / 12-13 / 12$ & $75 \%$ \\
\hline
\end{tabular}




\section{Conclusions and perspectives}

In this study, we aimed at demonstrating the feasibility to

detect tillage and irrigation operations using optical and radar satellite data with high spatial resolution $(\sim 10 \mathrm{~m})$ and temporal repetitiveness (a few days). The demonstration was performed using five images (three from FORMOSAT and two from ASAR) acquired within one week at the beginning of the wheat cropping season in the semi-arid Marrakech/Tensift plain. Simple mapping algorithms, i.e. band thresholding and decision tree, were applied on these images with two objectives: (1) classify soil surface states in relation with land cover and tillage practices and (2) detect the agricultural operations that occurred during the week of study.

FORMOSAT and ASAR images were found complementary to classify soil surface states. On one hand, it was shown that recently harrowed fields can be discriminated from ploughed fields on FORMOSAT images. On the other hand, the high sensitivity of ASAR data to surface roughness was useful to distinguish smooth surfaces (non-cultivated areas or wheat fields not prepared for sowing) from others (ploughed or recently harrowed fields). In this experiment, there was thus a noticeable complementarity of the two sensors, beyond the increase of the temporal density of observations.

The most innovative part of this research concerns the detection of the agricultural operations that occurred during one week. There is a general stability of FORMOSAT successive observations due to constant viewing angles. This allowed to fully take advantage of the sensitivity of reflectances to soil surface states. In contrast, the use of ASAR data is less trivial due to the variation of the sun-target-sensor geometry from the first observation to the second, the saturation of the radar response to surface roughness and the high heterogeneity of the area of study. Nevertheless, large spatial variations of reflectances and backscattering coefficients were observed, even between fields belonging to the same category of surface roughness/soil management practices. Despite this variability, drastic changes caused by ploughing or irrigation were identified without ambiguity and with accuracy in their timing.

The conditions prevailing during the experiment were optimal: no clouds, low and uniform soil moisture, and absence of vegetation. Rain events, resulting in a uniform variation of satellite observations (drop of reflectances and rise of backscattering coefficients), are obviously one of the main limitation of such change detection analysis.

Besides this limitation, which is not often encountered in semiarid areas, one major interest of our approach is the possibility to monitor agricultural operations at the beginning of the agricultural season. The perspectives concern real-time updating of land use maps (proportion of cultivated land, distribution of sowing dates,

). This appears promising to establish prior estimates of seâsonal crop water needs and to refine irrigation planning. The approach could be incorporated in decision support systems in agricultural Q2 water management and planning at a regional scale (see for instance Leenhardt et al., 2004; Satti and Jacobs, 2004; Simonneaux et al., 2007).

\section{Acknowledgements}

This study was conducted within the framework of the SudMed project coordinated by IRD/CESBIO and University of Marrakech (UCAM, Université Cadi Ayyad de Marrakech). In addition to IRD, this research has been supported by the PLEIADeS project of the European Commission (Contract 4 GOCE 037095), the "Programme d'Action Intégrée du Comité Mixte Interuniversitaire Franco-Marocain" (PAI Volubilis 06/148), and the French "Programme National de Télédétection Spatiale" (PNTS). Rachid Hadria was supported by a postdoc fellowship of French National Research Center (CNRS,
Centre National de Recherche Scientifique). We acknowledge NSPO, SPOT-Image for the delivery and the processing FORMOSAT images and the French National Space Agency (CNES, Centre National d'Etudes Spatiales) for its processing. ENVISAT/ASAR images were provided by ESA as part of a "Category-1 data use" proposal (AOE443, PI: Dr. E. Mougin). The authors are endebted to the staff and the directors of SudMed regional partners, especially ORMVAH (Office Regional de Mise en Valeur Agricole du Haouz) for their collaboration in field survey. The authors are gratefull to E. Mougin, A. Chehbouni, B. Mougenot, O. Hagolle (CESBIO), A. Olioso (INRA), S. Khabba (UCAM) and M. Zribi (CETP) for their scientific help during the course of this study.

\section{References}

Aboudrare, A., Debaeke, P., Bouaziz, A., Chekli, H., 2006. Effects of soil tillage and fallow management on soil water storage and sunflower production in a semiarid Mediterranean climate. Agricultural Water Management 83, 183-196.

Altesse, E., Bolognani, O., Mancini, M., 1996. Retrieving soil moisture over bare soil from ERS 1 synthetic aperture radar: sensitivity analysis based on a theoretical surface scattering model and field data. Water Resources Research 32,653-661.

Bastiaanssen, W.G.M., Allen, R.G., Droogers, P., D'Urso, G., Steduto, P., 2007. Twentyfive years modeling irrigated and drained soils: state of the art. Agricultural Water Management 92, 111-125.

Beaudoin, A., Le Toan, T., Gwyn, Q.H.J., 1990. SAR observations and modeling of the C-band backscatter variability due to multiscale geometry and soil moisture. IEEE Transactions on Geoscience and Remote Sensing 28 (5), 886-895.

Benallegûe, M., Taconet, O., Vidal-Madjar, D., Normand, M., 1995. The use of radar backscattering signals for measuring soil moisture and surface roughness. Remote Sensing of Environment 53, 61-68.

Boote, K.J., Jones, J.W., Pickering, N.B., 1996. Potential uses and limitations of crop models. Agronomy Journal 88, 704-716.

Casa, R., Lo Cascio, B., 2008. Soil conservation tillage effects on yield and water use efficiency on irrigated crops in central Italy. Journal of Agronomy \& Crop Science $194,310-319$

Chahinian, N., Moussa, R., Andrieux, P., Voltz, M., 2006. Accounting for temporal variation in soil hydrological properties when simulating surface runoff on tilled plots. Journal of Hydrology 326, 135-152.

Chappell, A., Zobeck, T.M., Brunner, ${ }^{\wedge} \mathrm{G} ., 2006$. Using bi-directional soil spectral reflectance to model soil surface changes induced by rainfall and wind-tunnel abrasion. Remote Sensing of Environment 102, 328-343.

Chehbouni, A., Escadafal, R., Boulet, G., Duchen̂in, B., Simonneaux, V., Dedieu, G. Mougenot, B., Khabba, S., Kharrou, H., Merlin, O., Chaponnière, A., Ezzahar, J., Erraki, S., Hoedjes, J., Hadria, R., Abourida, A., Cheggour, A., Raibi, F., Hanich, L., Guemouria, N., chehbouni, Ah., Olioso, A., Jacob, F., Sobrino, J. An integrated modelling and remote sensing approach for hydrological study in arid and semi-arid regions: the SUDMED Program. International Journal of Remote Sensing, in press.

Chern, J.-S., Wua, M., Lin, S., 2006. Lesson learned from FORMOSAT-2 mission operations. Acta Astronautica 59, 344-350.

Chern, J.-S., Ling, J., Wenig, S.L., 2008. Taiwan's second remote sensing satellite. Acta Astronautica 63, 1305-1311.

Cierniewski. J., 1989. The influence of the viewing geometry of bare soil surfaces on their spectral response in the visible and near infrared. Remote Sensing of Environment 27, 135-142

Conant, R.T., Eastêr, M., Paustian, K., Swan, A., Williams, S. Impacts of periodic tillage on soil C stocks: a synthesis. Soil Tillage Research. doi:10.1016/j.still.2006. 12.006, in press.

Davidson, M., Le Toan, T., Mattia, F., Satalino, G., Manninen, T., Verhoef, N., Borgeaud, M., 2000. On the characterization of agricultural soil roughness for radar remote sensing studies. IEEE Geoscience and Remote Sensing 38 (2), 630-640.

Duchemin, B., Hadria, R., Er-Raki, S., Boulet, G., Maisongrande, P., Chehbouni, A., Escadafal, R., Ezzahar, J., Hoedjes, J., Karroui, H., Khabba, S., Mougenot, B., Olioso, A. Rodriguez, I-C. Simonneaux, V., 2006. Monitoring wheat phenology and irrigation in Center of Morocco: on the use of relationship between evapotranspiration, crops coefficients, leaf area index and remotely sensed vegetation indices. Agricultural and Water Management $79, \hat{1}-27$.

Duchemin, B., Hagolle, O., Mougenot, B., Simonneaux, V., Benhadj, I., Hadria, R. Ezzahar, J., Hoedjes, J., Khabba, S., Kharrou, M.H., Boulet, G., Dedieu, G., Er-Raki, S., Escadafal, R., Olioso, A., Chehbouni, A.G., 2008a. Agrometerological study of semi-arid areas: an experiment for analysing the potential of FORMOSAT-2 time series of images in the Tensift-Marrakech plain. International Journal of Remote Sensing 29 (17-18), 5291-5300.

Duchemin, B., Maisongrande, P., Boulet, G., Benhadj, I., 2008b. A simple algorithm for yield estimates: calibration and evaluation for semi-arid irrigated winter wheat monitored with ground-based remotely-sensed data. Environmental Modelling and Software 23, 876-892.

Er-Raki, S., Chehbouni, A, Guemouria, N., Duchemin, B., Ezzahar, J. Hadria, R., 2007. Combining FAO-56 model and ground-based remote sensing to estimate water consumptions of wheat crops in a semi-arid region. Agricultural Water Management Journal 87, 41-54. 
G Model

AGWAT 2756 1-8

8

R. Hadria et al./Agricultural Water Management $x x x$ (2009) $x x x-x x x$

595

596

598

599

600

602

603

604

606

607

608

610

611

612

613
614

614

616
617

618

619

620

621

623

624

626

627

628
629

630

631

633

634
635

636
637

638
Faivre, R., Leenhardt, D., Voltz, M., Benoît, M., Papy, F., Dedieu, G., Wallach, D., 2004. Spatialising crop models. Agronomic 24, 205-217.

Fund, A.K., Li, Z., Chen, K.S., 1992. Backscattering from a randomly rough dielectric surface. IEEE Transactions on Geoscience and Remote Sensing 30, 356-369.

Guérif, J., Richard, G., Dürr, C., Machet, J.M., Recous, S., Roger-Estrade, J., 2001. A review of tillage effects on crop residue management, seedbed conditions and seedling establishment. Soil \& Tillage Research 61, 13-32.

Hadria, R., Duchemin, B., Lahrouni, A., Khabba, S., Er-Raki, S., Dedieu, G., Chehbouni, A., 2006. Monitoring of irrigated wheat in a semi-arid climate using crop modelling and remote sensing data: impact of satellite revisit time frequency. International Journal of Remote Sensing 27, 1093-1117.

Hadria, R., Khabba, S., Lahrouni, A., Duchemin, B., Chehbouni, A.G., Ouzine, L., Carrion, J., 2007. Calibration and validation of the shoot growth module of STICS crop model: application to manage irrigation water in the Marrakesch/Al Haouz Plain. Arabian Journal for Science and Engineering 32, 87-101.

Hagolle, O., Dedieu, G., Mougenot, B., Debaecker, V., Duchemin, B., Meygret, A., 2008. Correction of aerosol effects on multi-temporal images acquired with constant viewing angles: application to FORMOSAT images. Remote Sensing of Environmont 112, 1689-1701.

Jacquemoud, S., Bares, E., Hanocq, J.F., 1992. Modeling spectral and bidirectional soil reflectance. Remote Sensing of Environment 41, 123-132.

Jun, K., Cornelis, W.M., Schiettecatte, W., Lu, J., Yo, Y., Wu, H., Gabriels, D., De Never, S., Cai, D., Jun, J., Hartmann, R., 2007. Effects of different management practices on the soil-water balance and crop yield for improved dryland farming in the Chinese Loess Plateau. Soil and Tillage Research 96, 131-144.

Le Moan, T., Ribbed, F., Wang, L.-F., Floury, N., Ding, K.-H., Kong, J.A., Fajita, M., Kurosu, T., 1997. Rice crop mapping and monitoring using ERS-1 data based on experiment and modeling results. IEEE Transactions on Geoscience and Remote Sensing 35, 41-56.

Leenhardt, D., Trouvat, J.-L., Gonzalès, G., Pérarnaud, V., Prats, S., Bergez, J.-E., 2004. Estimating irrigation demand for water management on a regional scale. I. ADEAUMIS, a simulation platform based on bio-decisional modelling and spatial information. Agricultural Water Management 68, 207-232.

Lobs, D.A., Huffman, E., Reicosky, D.C., 2007. Importance of information on tillage practices in the modelling of environmental processes and in the use of environmental indicators. Journal of Environmental Management 82, 377-387.

Label, D.B., Aster, G.P., 2002. Moisture effect on soil reflectance. Soil Science Society of America Journal 66, 722-727.

Lopes, A., Nezry, E., Touzi, R., Lur, H., 1993. Structure detection and statistical adaptative speckle filtering in SAR images. International Journal of Remote Sensing 14, 1735-1758.

Mathieu, R., Puget, M., Cervelle, B., 1998. Relationships between satellite-based radiometric indices simulated using laboratory reflectance data and typic soil color of an arid environment. Remote Sensing of Environment 66, 17-28.
Moulin, S., Bondeau, A., Delécolle, R., 1998. Combining agricultural crop models and satellite observations from field to regional scales. International Journal of Remote Sensing 19, 1021-1036.

Mrabet, R., 2000. Differential response of wheat to tillage management systems in a semiarid area of Morocco. Field Crops Research 66, 165-174.

Muller, E., Décamps, H., 2000. Modeling soil moisture-reflectance. Remote Sensing of Environment 76, 173-180.

Nagler, P.L., Daughtry, C.S.T., Goward, S.N., 2000. Plant litter and soil reflectance. Remote Sensing of Environment 71, 207-215.

Ogban, P.I., Babalola, O., 2002. Evaluation of drainage and tillage effect on watertable depth and maize yield in wet inland valleys in southwestern Nigeria. Agricultural Water Management 52, 215-231.

Quegan, S., Yu, J., 2001. Filtering of multichannel SAR images. IEEE Transactions on Geoscience and Remote Sensing 39, 2373-2379.

Rahman, H., Dedieu, G., 1994. SMAC: a simplified method for the atmospheric correction of satellite measurements in the solar spectrum. International Journal of Remote Sensing 15, 123-143.

Rosich, B., Meadows, P., 2004. Absolute calibration of ASAR level 1 products generated with PF-ASAR. Technical Note. European Space Agency, 26 pp. http://earth.esa.int/pub/ESA_DOC/ENVISAT/ASAR/ASAR_products_absolute_calibration_v1.5.pdf.

Satalino, G., Mattia, F., Davidson, M., Le Moan, T., Pasquarello, G., Borgeaud, M., 2003. On current limits of soil moisture retrieval from ERS SAR data. IEEE Transactions on Geoscience and Remote Sensing 40, 2438-2447.

Sati, S.R., Jacobs, J.M., 2004. A GIS-based model to estimate the regionally distribute drought water demand. Agricultural Water Management 66, 1-13.

Simonneaux, V., Duchemin, B., Kelson, D., Er-Raki, S., Olioso, A., Chehbouni, A.G., 2007. Using high resolution image time series for crop classification and evapotranspiration estimate over an irrigated area in south Morocco. Internetonal Journal of Remote Sensing 29, 95-116.

Skidmore, E.L., Dickerson, J.D., Shimmelpfennig, H., 1975. Evaluating surface-soil water content by measuring reflectance. Soil Science Society of American Proceedings 39, 238-242.

Ulaby, F.T., Fund, A.K., Moore, R.K., 1986. Microwave and Remote Sensing Active and Passive. Artech House, Norwood, MA.

Wagner, W., Lemoine, G., Borgeaud, M., Ret, H., 1999. A study of vegetation cover effects on ERS scatterometer data. IEEE Transactions on Geoscience and Remote Sensing $37(2)$, 938-948.

$\mathrm{Xu}, \mathrm{D}$., Mermoud, A., 2003. Modeling the soil water balance based on timedependent hydraulic conductivity under different tillage practices. Agricultural Water Management 63, 139-151.

Zribi, M., Baghdadi, N., Holah, N., Fain, O., 2005. New methodology for soil surface moisture estimation and its application to ENVISAT-ASAR multi-incidence data inversion. Remote Sensing of Environment 96, 485-496.

639
640
641
642
643
644
645
646
647
648
649
650
651
652
653
654
655
656
657
658
659
660
661
662
663
664
665
666
667
668
669
670
671
672
673
674
675
676
677
678
679
680
681
682
6

683

Please cite this article in press as: Hadrian, R., et al., Combined use of optical and radar satellite data for the detection of tillage and

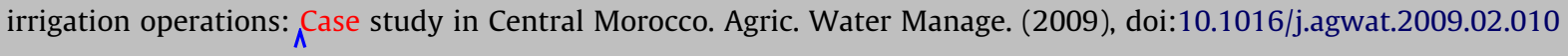

